\title{
Tinjauan Teologis Tentang Ibadah Bagi Pelaksanaan Misi Allah
}

\section{Theological Review of Worship For the implementation of God's Mission}

\author{
Yonatan Sumarto ${ }^{1}$ * \\ 1) Program Magister Sekolah Tinggi Agama Kristen Negeri Toraja, Makale \\ ${ }^{*}$ Penulis Korespondensi:yonatansumarto@yahoo.co.id
}

Received: 21 July 2018/Revised: 07 November 2018 /Accepted: 12 December 2018

\begin{abstract}
Abstrak
Tulisan ini bertujuan untuk menjelaskan tinjauan teologis tentang ibadah bagi pelaksanaan misi Allah. Metode yang digunakan adalah kualitatif deskriptif dengan kajian kepustakaan. Kesimpulannya adalah Ibadah sebagai penyembahan kepada TUHAN Allah sekaligus sebagai pengujian tindakantindakan misioner warga gereja. Ibadah mengerakkan umat Allah untuk mengalami perjumpaan dengan Allah, dan kehendak-Nya. Respons umat Allah adalah melaksanakan misi Allah bagi dunia. Integritas ibadah adalah mengenal kehendak Allah bagi misi-Nya di dunia melalui gerje, dan orang percaya.

Kata-kata kunci: ibadah, misi, gereja, spiritual, visi

This paper aims to explain the theological review of worship for the implementation of God's mission. The method used is descriptive qualitative with literature review. The conclusion is that worship is worshiping the Lord God as well as testing missionary actions of the church members. Worship moves God's people to experience an encounter with God, and His will. The response of God's people is to carry out God's mission for the world. Integrity of worship is knowing God's will for His mission in the world through the church, and believers.
\end{abstract}

Keywords: worship, mission, church, spiritual, vision

\section{Pendahuluan}

Gereja bukan hanya mempunyai misi, melainkan seluruh kehidupan gereja itu adalah misi. Karena itu dapat dikatakan bahwa jati diri gereja adalah misi. Gereja baru benar-benar gereja apabila ia adalah gereja yang misioner. Gereja bersifat misioner, sebegitu mendalam sehingga kalau ia berhenti bersifat misioner, ia tidak sekadar gagal dalam 
salah satu tugasnya, lebih daripada itu ia telah berhenti menjadi Gereja. ${ }^{1}$ Perjalanan sejarah, gereja seharusnya menandakan bahwa ia adalah gereja yang misioner. ${ }^{2}$ Tanpa rasa panggilan yang kuat terhadap pekerjaan misionernya, gereja tidak dapat menganggap dirinya bersifat am atau bersifat rasuli. ${ }^{3}$ Gereja dapat berkembang jika jemaatnya misioner atau terlibat dalam kegiatan-kegiatan misi. Karena itu, gereja harus memobilisasi warga jemaatnya untuk berpartisipasi aktif dalam pemberitaan Injil, sehingga dengan demikian gereja itu dapat disebut sebagai gereja yang misioner.

Gereja yang berkembang adalah gereja yang sehat. Gereja yang sehat dan bertumbuh memiliki ciri dan tanda yang khusus. ${ }^{4}$ Menurut $C$. Peter Wagner, gereja yang sehat dan bertumbuh memiliki keseimbangan hubungan dinamis pola hidup, dan ibadah jemaat. ${ }^{5}$

Tulisan ini bertujuan untuk mengkaji tinjauan teologis tentang ibadah dari Perjanjian Lama, dan Perjanjian Baru, dan bagaimana itu dapat mengimplikasikan misi Allah bagi gereja masa kini. Penulis akan menjelaskan tinjauan teologis tentang ibadah termasuk di dalamnya adalah hakikat ibadah dari berbagai perspektif yang dikaitkan dengan kebenaran Alkitab.

\section{Metode}

Metode yang digunakan adalah metode kualitatif untuk mengkaji teologi tentang ibadah, dan implikasi misi Allah bagi gereja. Berbagai sumber informasi baik Alkitab, buku, dan jurnal digunakan untuk mendukung argumen penulis dalam tulisan ini. ${ }^{6}$

\section{Pembahasan}

\section{Makna Kata Ibadah dalam Alkitab}

Konsep esensial dari istilah ibadah adalah pelayanan. Istilah-istilah abòdà (Ibrani), dan latreia (Yunani) berarti pekerja budak atau pelayan upahan. ${ }^{7}$ Dalam bahasa Ibrani kata kerja dari abòdà adalah 'abad yang

${ }^{1}$ J. Andrew Kirk, Apa itu Misi? (Jakarta: BPK Gunung Mulia, 2012), 36.

${ }^{2}$ Yakob Tomatala, Teologi Misi (Jakarta: YT Leadership Foundation, 2003), 161.

${ }^{3}$ J. Andrew Kirk, Apa itu Misi? (Jakarta: BPK Gunung Mulia, 2012), 36.

${ }^{4}$ Yakob Tomatala, Teologi Misi (Jakarta: YT Leadership Foundation, 2003), 220.

${ }^{5}$ Yakob Tomatala, Teologi Misi (Jakarta: YT Leadership Foundation, 2003), 220.

Tomatala mengutip pernyataan Wagner.

${ }^{6}$ Hengki Wijaya, Analisis Data Kualitatif Ilmu Pendidikan Teologi (Makassar: Sekolah Tinggi Theologia Jaffray, 2018), 94-100.

${ }^{7}$ J. G. S. S. Thomson, "Worship" in J. D. Douglas (eds). The New Bible Dictionary (London: Inter-Varsity Press, 1982), 1340. 
berarti "bekerja," "bekerja sebagai buruh," "membanting tulang", "mengolah tanah", "membajak", "melayani", "bekerja sebagai budak", "beribadat". Sedangkan kata bendanya adalah ébêd yang berarti "buruh", "pelayan", "budak", "orang jaminan", "penyembah". ${ }^{8}$ Kata 'abad pertama kali digunakan dalam kitab Kejadian saat Adam memelihara taman Eden, dan setelah Adam harus bekerja keras saat jatuh dalam dosa. Kata ini digunakan kembali saat bangsa Israel keluar dari tanah Mesir dengan tujuan beribadah ('abad) kepada Allah. Dengan demikian tujuannya adalah beribadah kepada Allah.

Selain itu kita juga mengenal istilah liturgi yang berasal dari bahasa Yunani leitourgia. Kata ini terbentuk dari kata dasar ergon (=karya), yang merupakan kata sifat untuk kata benda laos (=bangsa). Istilah ini mulanya dipakai untuk menunjuk pada pelayanan kepada lembaga politik, kemudian menjadi pelayanan pada umumnya, lalu menjadi istilah yang menunjuk pada pelayanan penyembahan. Dalam Perjanjian Baru, istilah ini dipakai untuk menunjuk pada persekutuan doa, dan puasa (Kis. 13:2), untuk pengumpulan bantuan bagi Jemaat di Yerusalem (Rm. 15:27 dan 2 Kor. 9:12) atau bantuan keuangan untuk Paulus (Flp. 2:25). Ibadah adalah leitourgia yang mengatur relasi antara Allah dan manusia, sedangkan misi adalah leitourgia yang mengatur relasi antara sesama manusia.

\section{Tinjauan Teologis tentang Ibadah}

Ibadah adalah Perjumpaan dengan TUHAN

Setelah kita melihat dari sisi terminologi, maka sekarang kita hendak melihat hubungan ibadah dan misi itu dari hakikat ibadah itu sendiri. Ibadah Jemaat pada hakikatnya adalah suatu pertemuan antara TUHAN Allah dan Jemaat. Ibadah pada satu sisi adalah perintah TUHAN Allah sebagaimana dengan tegas dikemukakan dalam dasa titah untuk hanya menyembah TUHAN Allah. Alasan TUHAN Allah membebaskan umat-Nya dari perbudakan di Mesir adalah agar mereka beribadah kepada TUHAN Allah (Keluaran 3:13; 5:3; 7:16; 8:1,20). Misi pembebasan umat ada kaitannya dengan ibadah kepada TUHAN Allah. Andrew Brake menegaskan bahwa apapun gaya penyembahan kepada Allah maka Allah menjumpai umat-Nya asalkan peneyembahan itu difokuskan hanya kepada diri-Nya. ${ }^{9}$

${ }^{8}$ Matt Redman, Menyembah dalam Roh dan Kebenaran (Yogyakarta: ANDI, 2010), 83; K. Feyerabend, Langenscheidt's Hebrew e English Dictionary to the Old Testament (Berlin: Langenscheidt KG, 1957), 237-238.

${ }_{9}^{9}$ Andrew Brake, Spiritual Formatian: Menjadi Serupa dengan Kristus (Bandung: Kalam Hidup, 2014), 23. 
Sejarah kehidupan umat Allah, mulai dari cikal-bakalnya, baik sejak Abraham maupun pada peristiwa pembebasan dari Mesir dimotivasi oleh ibadah kepada TUHAN Allah. Abraham memenuhi panggilan TUHAN Allah untuk menuju ke Kanaan. Dalam perjalanan misioner itu ia tidak pernah melupakan untuk mendirikan "mezbah bagi TUHAN dan memanggil nama TUHAN" (Kej. 12:7-8; 13:3-4, 18). Akhirnya, pada penghujung sejarah, yakni penggenapan keselamatan akan ditandai dengan ibadah di kota surgawi (Why. 19:6-10 dan 21:22).

\section{Ibadah Melahirkan Visi dan Misi}

Pertemuan antara TUHAN Allah dengan manusia selalu melahirkan visi dan misi sehingga kemudian mereka mempersembahkan seluruh hidup mereka bagi TUHAN. ${ }^{10}$ Perjumpaan TUHAN Allah dengan Abram ditandai oleh TUHAN Allah berfirman kepada Abram untuk "pergi ke negeri" yang akan ditunjukkan oleh Allah sendiri. Misinya adalah untuk menjadi berkat (Kej. 12:1-3). Dalam proses menunaikan misinya itu berkali-kali Alkitab menyaksikan bahwa TUHAN Allah berfirman atau mengutus malaikat bahkan berdialog dengan Abram. TUHAN Allah berfirman kepada Abram untuk memastikan dan menyegarkan kembali visi dan misinya (13:14-17). TUHAN Allah menjumpai Abram dalam suatu penglihatan ketika ia mulai meragukan janji TUHAN Allah sebab ia belum juga dikaruniai anak (15:1-5). Perjumpaan itu mengembalikan kepercayaan Abram kepada TUHAN Allah dan TUHAN Allah memperhitungkannya sebagai kebenaran (15:6). Dalam perjumpaan selanjutnya TUHAN Allah memberikan visi kepada Abram yaitu pemberian tanah Kanaan (15:7, 1721) maupun penggenapan bahwa keturunannya akan menjadi bangsa budak di negeri asing (15:8-16). Hal yang samapun terjadi kembali melalui suatu dialog dengan tiga orang utusan TUHAN Allah (18:1-15).

Dalam rangka misi untuk menjadi berkat bagi segala bangsa, maka Abraham pun mensyafaatkan kota Sodom dan Gomora (18:16-33). Perjumpaan TUHAN Allah dengan Abraham adalah juga dimaksudkan untuk menguji kesetiaan Abraham pada TUHAN Allah dan dengan demikian pada visi dan misi yang dipercayakan kepadanya. Itulah maksud dari perjumpaan TUHAN Allah dengan Abraham di bukit Moria (22:1-10). Karena Abraham menunjukkan kesetiaannya maka TUHAN Allah mempertegas kembali janji-janji-Nya untuk menyertai dan memberkatinya dalam menunaikan misinya.

Dalam Perjanjian Baru, tokoh Yesus sendiri memulaikan misi-Nya dengan ibadah berbentuk Puasa (Mat. 4:1-11; Mrk. 1:12-13; Luk. 4:1-13). Penginjil Lukas melukiskan Yesus sesudah berpuasa, Ia datang ke

${ }^{10}$ G. Barna, Mengejawantahkan Visi ke dalam Aksi (Jakarta: Metanoia, 1998), 66-83. 
Nazareth, di mana Ia melakukan kebiasaannya untuk ke sinagoge pada setiap sabat (Luk. 4:16). Dalam hidup dalam pelayanan-Nya, doa mempunyai tempat yang penting. Tiap-tiap kali Ia mencari persekutuan dengan Allah di dalam doa-Nya. Kadang-kadang lama sekali, "semalammalaman" (Luk. 6:12; 9:28; 10:21-2; 11:1; 22:39-46). Yesus berdoa bukan hanya dalam saat-saat menyendiri, tetapi juga dalam ibadah-ibadah umat Allah. Paling tidak ada tiga alasan mengapa Yesus juga beribadah: a) karena Ia tahu bahwa Allah hadir di mana saja; b) sinagoge menghubungkan antara masa lalu dan masa kini; c) sinagoge adalah tempat persekutuan." Dengan demikian maka segala pekerjaan-Nya, Ia lakukan dalam persekutuan dengan Allah. ${ }^{12}$ tetapi juga dalam relasinya dengan sesama manusia dalam dimensi waktu, serta dengan alam sekitar. Ibadah, dan misi Yesus mencerminkan pola hubungan yang utuh. Demikian juga pengalaman Paulus yang diekspresikan dalam suratnya kepada Jemaat di Roma yang menyebutkan bahwa persembahan tubuh yang hidup, kudus dan berkenan kepada Allah adalah ibadah yang sejati (12:1).

\section{Ibadah adalah Disiplin Rohani}

Dari uraian di atas kita belajar bahwa ibadah melahirkan disiplin spiritualitas yang sangat penting dalam memperkuat motivasi untuk terlibat dalam misi. Tempat dari disiplin spiritual iman orang percaya ditemukan dalam relasinya yang konkrit dari keterlibatan orang-orang percaya dalam persekutuan jemaat di tingkat basis.

Dalam Perjanjian Lama, pertobatan berasal dari kata shûwb yang berarti berbalik atau kembali kepada Allah, dengan segenap hati, jiwa dan kekuatan seperti antara lain ditemukan dalam 2 Raja-raja 23:25. Cakupan pertobatan melampaui dukacita-penyesalan dan perubahan tingkah laku lahiriah. Dalam Perjanjian Baru, kata metanoia berarti menjangkau makna terdalam daripada belajar. Melalui belajar, kita menemukan kembali diri kita sendiri. Melalui belajar kita menjadi mampu untuk berbuat sesuatu, memahami TUHAN Allah, dunia dan hubungan kita dengannya, serta memperluas kapasitas untuk menciptakan, menjadi bagian daripada proses kehidupan yang generatif. ${ }^{13}$

Dalam kerangka inilah maka ibadah menemukan maknanya yakni untuk memperkuat iman berdasarkan Injil untuk terlibat dalam perju-

${ }^{11}$ W. R. Bowie, "Exposition of the Gospel According to St. Luke" in G. A. Butrick et.al.

(eds), The Interpreter's Bible, Vol. 8. (Nashville: Abingdon Press, 1991), 89-90.

${ }^{12} \mathrm{~J}$. Ch. L. Abineno, DOA Menurut Kesaksian Perjanjian Baru (Jakarta: BPK Gunung Mulia, 1992), 1-2.

${ }_{13}$ P. M. Senge, The Fifth Dicipline (New York: Dobleday Currency, 1990), 10, 14. 
angan hidup sehari-hari. Dari situlah ditemukan sumber daya spiritual umat. ${ }^{14}$ Tetapi spiritualitas tanpa moralitas akan melahirkan fanatisme yang membabi buta, seperti spiritualitas orang Yahudi yang tega menganiaya bahkan membunuh orang-orang yang percaya kepada Kristus, seperti disaksikan dalam Kisah Para Rasul 6:8.

Ibadah bukan sekadar pelayanan penyembahan kepada TUHAN Allah, tetapi dialog, dan pelayanan kepada sesama. Misalnya, dialog antara Yesus dengan seorang ahli Taurat sebagaimana disaksikan dalam Lukas 10:25-37, yang diakhiri dengan perumpaaan tentang orang Samaria yang murah hati, merupakan ungkapan pengajaran Yesus tentang ibadah, sebagai wujud kasih kepada TUHAN Allah dan kepada sesama. Khotbah Yesus di bukit, seperti disaksikan dalam Matius 5:23-24, menekankan bahwa ibadah itu bukan hanya memberikan persembahan tetapi juga kesediaan berdamai dengan sesama. Yohanes 4:20-24 berbicara tentang beribadah dengan roh dan kebenaran. Dalam tulisan Tison, dan Jermia Djadi disimpulkan bahwa ibadah yang benar ialah memiliki hati yang menyembah, hidup dalam kekudusan, hidup dalam persekutuan orang percaya, dan saling memerhatikan satu dengan yang lain. ${ }^{15}$ Dengan demikian perjumpaan dengan Tuhan melalui penyembahan adalah sikap hati yang benar, dan mengalami diri-Nya secara pribadi. ${ }^{16}$

Pemahaman di seputar ibadah sebagai perjumpaan dengan TUHAN memberikan kepada kita suatu gambaran yang jelas betapa tidak mungkin ibadah itu dilepaskan dari misi. Ibadah adalah pangkalan untuk bermisi. Sebab ibadah berperan untuk membangun disiplin spiritual dengan berfokus kepada Tuhan untuk melaksanakan misi-Nya.

\section{Misi dan Strateginya}

Pengertian Misi

Istilah misi berasal dari teks Alkitab versi Latin missio (pengutusan) yang berasal dari kata kerja bahasa Yunani apostello (mengutus). Dalam Perjanjian Baru, orang yang diutus atau rasul (apostolos) dikenakan kepada Yesus (Ibr. 3:1). Tapi juga dikenakan kepada para nabi dan rasul yang diutus oleh Allah (Luk. 1l:49) dan mereka yang diutus oleh jemaat-jemaat seperti Titus dan temantemannya serta Epafroditus (2 Kor. 8:23; Flp 2:25). Tapi di atas se-

\footnotetext{
${ }^{14}$ Kim Yong Bock, Messiah and Minjung: Christ's Solidarity with the Paople for New Life (Hongkong: CCA-URM, 1992), 65.

${ }^{15}$ Tison, Jermia Djadi, "Pengajaran Tentang Ibadah Berdasarkan Surat Ibrani

10:19-25 Dan Implimentasinya Dalam Kehidupan Orang Percaya Pada Masa Kini," Jurnal Jaffray 1l, no. 1 (April 2, 2013): 63.

${ }^{16}$ Hengki Wijaya, "Kajian Teologis Tentang Penyembahan Berdasarkan Injil Yohanes 4:24," Jurnal Jaffray 13, no. 1 (March 16, 2015): 94.
} 
muanya itu, rasul-rasul terutama menunjuk pada kelompok orang yang menempati kedudukan terkemuka dalam Gereja purba. Istilah ini kemudian sering diartikan sebagai "diutus dengan maksud tertentu."17 Yang pasti para pelaku misi adalah mereka yang menjadi utusan Allah.

Perjanjian Baru juga menggunakan kata "bersaksi" untuk menekankan ekspresi dari kehidupan Gereja yang terarah keluar. ${ }^{18}$ Penekanan dari hakikat misi tidak terletak pada aktivitas, meskipun aktivitas tetap ada, tapi pada hidup dan relasi-relasinya. Misi tidak menekankan pada apa yang kita buat sebagai anak-anak Allah. Misi adalah suatu kehidupan yang menyambut maksud Allah untuk kita dan untuk semua ciptaan. Misi adalah sekonkret kehidupan dari suatu umat. ${ }^{19}$

Misi Kristen mengungkapkan hubungan yang dinamis antara Allah dan dunia. Perbedaan-perbedaan pandangan dalam mendefinisikan misi itu tidak terletak pada ada tidaknya relasi antara Allah dan dunia, melainkan pada pandangan tentang sifat dan bentuk dari hubungan antara Allah dan dunia. Dan bahwa cara pandang terhadap hubungan Allah dan dunia itupun banyak dipengaruhi oleh lingkungan dan situasi di mana gereja hadir pada masanya. Bosch, yang mengutip Hoekendijk, bahwa keseluruhan keberadaan Kristen harus dicirikan sebagai keberadaan misioner. ${ }^{20}$ Bahwa misi dan ibadah itu berkaitan dan bahkan merupakan dua sisi dari mata uang yang sama dapat ditunjukkan pada pemberlakuan dikaiosune sebagai salah satu tujuan misi. Istilah dikaiosune menunjuk pada kebenaran dalam arti hubungan dengan TUHAN Allah dan keadilan yang menunjuk pada hubungan dengan sesama. Dikaiosune adalah iman di dalam perbuatan, praktik devosi atau menurut Matius 6:1 sebagai perilaku yang benar di hadapan Bapa. ${ }^{21}$

Jati diri Kristen dapat dikatakan sebagai pada satu sisi kesatuannya dengan Allah, dan pada sisi lain identifikasi orang Kristen bersama dengan rakyat atas dasar Injil. "Orang Kristen menemukan identitas sejati mereka bila mereka terlibat di dalam misi, dalam berkomunikasi dengan orang lain tentang cara hidup baru, penafsiran baru tentang realitas dan tentang Allah, dan dalam menyerahkan diri mereka bagi pembebasan dan keselamatan bagi orang lain." ${ }^{22}$ Tulisan

${ }_{17}$ A. F. Walls, “Apostle” in J. D. Douglas (eds). The New Bible Dictionary (London: Inter-Varsity Press, 1970), 48.

${ }^{18}$ K. C. Abraham, Liberative Solidarity: Contemporary Perspectives on Mission.

(Tiruvalla: Christava Sahitya Samithi, 1996), 10.

${ }^{19}$ Ibid., 10.

${ }^{20} \mathrm{~J}$. D. Bosch, Transformasi Misi Kristen: Sejarah Teologi Misi yang Mengubah dan

Berubah. (Jakarta: BPK Gunung Mulia, 1997), 13-15.

${ }^{21}$ Ibid, 110-112.

${ }^{22} \mathrm{Ibid}, 129$. 
Lukas dalam Injil Lukas dan Kisah Para Rasul menunjukkan mandat misi Allah untuk menjadi saksi Kristus bagi semua bangsa dengan menyaksikan kabar baik tentang Yesus mengenai kematian, dan kebangkitan-Nya. ${ }^{23}$

\section{Ibadah Sebagai Pengujian Tindakan Misioner}

Kejadian 42 bercerita tentang keluarga Yakub ketika mereka menghadapi ancaman kelaparan. Tanggapan terhadap masalah itu juga bervariasi.

Pertama, menyentuh akal manusia. Anak-anak Yakub kehilangan akal ketika menghadapi ancaman kelaparan. Mereka kebingungan. Tidak tahu apa yang hendak diperbuat. Sampai-sampai Yakub harus menegor mereka: "Mengapa kamu berpandang-pandangan saja?" (ayat 1). Tentu saja keadaan anak-anaknya berbeda dengan Yakub. Dia tidak kehilangan akal. Dia mencari dan kemudian menemukan informasi bahwa di Mesir ada makanan. Dia membuka pikiran dan akal anakanaknya. Karena di antara mereka "baku dengar" maka segera ada rencana dan tindakan untuk mengatasi krisis pangan yang di hadapi (ayat 1-5).

Kedua, masalah itu menyentuh kesadaran manusia. Ketika Yusuf menguji saudara-saudaranya, maka reaksi mereka adalah "Betul-betullah kita menanggung akibat dosa kita terhadap adik kita....Sekarang darahnya dituntut daripada kita" (ayat 21-22). Masalah itu menyentuh kesadaran manusia akan memunculkan juga kesadaran akan kesalahan dan dosa mereka. Mereka tidak mempersalahkan Yusuf (yang tidak mereka kenal) atau orang lain.

Ketiga, menyentuh hati. Hal itu terutama itu menjadi nyata dalam rasa duka Yakub, ketika mengetahui bahwa Simeon dijadikan sandera, lalu Benyamin harus diikut sertakan bila ingin Simeon dibebaskan. Malah kejadian itu telah menyentuh kembali luka lama Yakub karena peristiwa hilangnya anak terkasih, Yusuf. Segi positifnya adalah menggugah kembali hubungan kasih antara Yakub dan anak-anaknya, bahkan hubungan kasih antara sesama anak-anak. Sebab bukankah Yusuf terharu dan bahkan sampai menangis ketika bertemu dengan saudara-saudaranya? Bukankah juga saudara-saudaranya antara lain Ruben mengingat kembali akan tindakan mereka terhadap Yusuf?

Keempat, menyentuh iman. "Apakah juga yang diperbuat Allah terhadap kita?", adalah suatu pertanyaan yang terungkapkan di antara anak-anak Yakub ketika mereka dalam keadaan gentar dan bingung. Artinya di tengah-tengah kebimbangan dan ketakutan, masih ada

${ }^{23}$ Christopher J. H. Wright, The Mission of God: Unlocking the Bible's Grand Narrative (Downers Grove, Ill: IVP Academic, 2006). 
perasaan bahwa mereka sedang berurusan dengan cara Allah yang misterius, yang penuh rahasia; ketakutan mereka bercampur dengan iman.

Dari cerita ini kita bisa menarik kesimpulan bahwa tanggapan atas krisis atau masalah yang sedang dihadapi dihubungkan dengan peranan TUHAN Allah. Pertanyaan "Apakah juga yang diperbuat Allah terhadap kita?" adalah pertanyaan ujian yang hendak dicari jawabannya dalam relasi mereka dengan TUHAN Allah.

Lukas 10:17-24 berisikan percakapan antara ketujuhpuluh murid Yesus dengan Sang Guru, setelah mereka kembali dari tugas pengutusan yang dipercayakan kepada mereka oleh Yesus. Yesus yang berkomunikasi dengan Sang Bapa, kemudian melanjutkan komunikasi-Nya dengan para murid. Ia menyatakan mereka sebagai orang yang berbahagia karena melihat apa yang belum banyak dilihat orang termasuk banyak nabi dan raja, tetapi tidak melihatnya, dan ingin mendengar apa yang mereka dengar, tetapi tidak mendengarnya (Luk. 10:23-24).

Percakapan ini merupakan evaluasi/penilaian atau pengujian atas tindakan misioner mereka di hadapan TUHAN. Dalam penjelasan sebelumnya sudah ditegaskan bahwa hakikat dari ibadah adalah perjumpaan dengan TUHAN. Jadi, dialog ini bisa kita catat sebagai cerminan dari ibadah yang fungsinya adalah untuk menguji atau menilai hasil pekerjaan misi yang sudah dilakukan, serentak merencanakan langkah selanjutnya. Sebagai tolok ukur pengujian atau penilaian adalah kehendak, rencana dan tindakan TUHAN Allah sebagai mana nyata dan yang dinyatakan di dalam Yesus Kristus.

Dalam 2 Korintus 13:5-10 Paulus menyerukan kepada Jemaat Korintus agar "Ujilah (peirazete) dirimu sendiri, apakah kamu tetap tegak di dalam iman. Selidikilah (dokimazete) dirimu! Apakah kamu tidak yakin akan dirimu, bahwa Kristus Yesus ada di dalam diri kamu? Sebab jika tidak demikian, kamu tidak tahan uji" (13:5). Seruan ini dikemukakan sebagai kesimpulan dari pembicaraan mengenai krisis yang terjadi antara Paulus dan jemaat di Korintus. ${ }^{24}$ Menguji menunjuk pada niat untuk membuktikan apakah seseorang berbuat baik atau jahat atau membuatnya jahat. Kata menguji selalu berkaitan dengan pengalaman atau suatu usaha. Sedangkan menyelidiki bermaksud untuk membuktikan bahwa seseorang itu baik dan dapat diterima. ${ }^{25}$ Dengan jelas terlihat bahwa menguji atau menyelidiki diri berarti melihat pada

${ }^{24}$ F. V. Filson, "The Second Epistle to the Corinthians: Introduction and Exegesis" in G.A. Butrick et.al. (eds), The Interpreter's Bible, Vol. 10 (Nashville: Abingdon Press, 1991), 419420.

${ }^{25}$ S. Zodhiates, The Hebrew-Greek Key Study Bible (Chattanooga-USA: AMG Publishers, 1986), 1683, 1720. 
diri sendiri, pada pengalaman sendiri yaitu pada sikap dan tindakan terhadap sesama, khususnya sikap jemaat Korintus terhadap Paulus.

Namun ukuran untuk menguji diri adalah apakah mereka tetap tegak di dalam iman dan apakah Kristus Yesus ada di dalam diri mereka. Hal itu dapat diuji melalui pertanyaan, sejauh manakah kita menemukan dalam diri kita kebutuhan dan keinginan untuk berdoa, untuk beribadah dan terhadap pesan-pesan Alkitab? Kualitas dari kesadaran akan kebutuhan-kebutuhan itu adalah ujian terhadap kemajuan diri. Semakin kita memiliki pengetahuan, semakin kita mencarinya. Semakin kasih Kristus bertumbuh dalam hati, semakin terdorong untuk mencari kehadiran-Nya dan bersekutu dengan Dia. ${ }^{26}$ Dalam hal ini, ibadah kita sangat penting untuk pembentukan identitas misi kita. ${ }^{27}$ Satu lagi definisi yang ditawarkan Wright bahwa "Misi Tuhan melibatkan umat Allah hidup di jalan-Nya di hadapan bangsa-bangsa." 28 Definisi ini memberikan perasaan tentang bagaimana kehendak Allah menggerakkan umat-Nya dalam misi-Nya. Ia akan menjadikan mereka sebagai alat-Nya untuk mewujudkan kehendak Tuhan. ${ }^{29}$

Dari bagian ini dapat disimpulkan bahwa dilihat dari segi istilahnya maka misi baik dalam arti pengutusan maupun kesaksian, merupakan pemberian diri pada pekerjaan atau pelayanan untuk memenuhi maksud-maksud TUHAN Allah bagi dunia dan manusia. Ini tak ada bedanya dengan pemahaman tentang ibadah. Pemahaman tentang misi yang mengacu pada Missio Dei ini dengan jelas bertemu dengan pemahaman tentang ibadah sebagai persembahan tubuh yang hidup, yang kudus dan berkenaan kepada Allah, yaitu ibadah yang sejati (Roma 12:1). Jadi ibadah yang sejati mewujud dalam penunaian misi yang bertolak dari ibadah penyembahan. Jadi seluruh hidup dalam relasi dengan TUHAN Allah dan sesama dilihat sebagai misi, tetapi dalam pemahaman ibadah juga sudah ditegaskan bahwa seluruh hidup ini adalah ibadah.

Dari Perjanjian Lama maupun Perjanjian Baru kita dapati bahwa misi pada hakikatnya adalah mengejawantahkan kehendak dan atau

\footnotetext{
${ }^{26}$ J. Reid, "The Second Epistle to the Corinthians: Exposition" in G.A. Butrick et.al. (eds), The Interpreter's Bible, Vol. 10 (Nashville: Abingdon Press, 1991), 420.

${ }^{27}$ Michael W. Goheen, "Nourishing Our Missional Identity: Worship and the Mission of God's People," In David J. Cohen and Michael Parsons (eds.), In Praise of Worship: An Exploration of Text and Practice (Eugene, OR: Wipf and Stock Publishers, Pickwick Publications, 2010), 33.

${ }^{28}$ Wright, The Mission of God.

${ }^{29}$ Michael W. Goheen, "Nourishing Our Missional Identity: Worship and the Mission of God's People," In David J. Cohen and Michael Parsons (eds.), In Praise of Worship: An Exploration of Text and Practice (Eugene, OR: Wipf and Stock Publishers, Pickwick Publications, 2010), 34.
} 
firman Tuhan bagi manusia dan dunia ini. Dalam terang pemahaman ini maka jelas bahwa baik ibadah maupun misi sama-sama berpusat pada firman Tuhan. Begitu juga dilihat dari strategi misi. Meskipun para ahli membeda-bedakan strategi proklamasi, kesaksian dan pelayanan; namun pada akhirnya ketiganya adalah satu kesatuan. Apalagi jika mengacu pada strategi misi Yesus yang memproklamasikan misi itu lewat kesaksian, dan tindakan pelayanan-Nya.

Mutlaknya relasi antara misi dan ibadah menjadi lebih jelas dalam kesaksian Alkitab yang memberitakan tentang putusnya hubungan antara ibadah dan misi. Kerasnya kecaman terhadap ibadah bukan karena para nabi bahkan Yesus sendiri tidak setuju dengan ibadah, tetapi karena ibadah itu tidak ditindaklanjuti dalam tindakan yakni misi.

\section{Peran Ibadah dalam Menunjang Pelaksanaan Misi bagi Warga Gereja} Menjadikan Jemaat Objek sekaligus Subjek Pemberitaan Firman

Ibadah atau penyembahan adalah suatu respons kepada Allah, dan hanya kepada-Nya segala kemuliaan, dan misi adalah panggilan bagi kita untuk mengundang orang lain untuk merespons untuk beribadah kepada-Nya. ${ }^{30}$ "Ibadah yang dipahami dan diterapkan sebagai penyembahan kepada Allah sekaligus sebagai pengujian tindakantindakan misioner warga gereja, lebih efektif sebagai pangkalan misi daripada ibadah yang hanya ditekankan pada penyembahan kepada Allah." Efektivitas itu bukan hanya terlihat dalam bertambahnya jumlah kehadiran dalam ibadah. Tapi hal itu juga menjadi kenyataan dalam pekerjaan mereka sehari-hari yang ditandai dengan semakin tingginya semangat dan motivasi kerja. Bahkan kelompok yang beribadah dan bekerja bersama itu ternyata juga memiliki posisi tawar menawar terhadap kekuasaan dan bahkan menjadi kekuatan sosial kontrol terhadap negara. Fungsi sosial kontrol merupakan ciri masyarakat sipil. Jadi salah satu cara untuk menjawab tantangan ke depan adalah dengan menjadikan ibadah sebagai penunjang pelaksanaan misi.

Upaya menata ibadah dalam menunjang pelaksanaan misi perlu dimulai dengan mengubah pola komunikasi dalam ibadah. Selama ini pola komunikasi ibadah-ibadah di kebanyakan jemaat didasarkan pada paradigma jemaat sebagai objek pemberitaan firman Tuhan. Paradigma ini menempatkan jemaat sebagai pihak yang mengkonsumsi. Firman adalah "suatu barang jadi" yang diberikan atau dilayankan kepada jemaat, atau meminjam istilah Kim Yong Bock, pre-packaged Gospel. Jemaat tidak mendapat kesempatan untuk "melihat" sendiri apa yang ada di balik realitas. 2012), 9.

${ }^{30}$ Sandra Van Opstal, The Mission of Worship (Downers Grove, Ill.: IVP Books, 
Dengan demikian proses penyadaran hanya terjadi bagi pemberita firman (pengkhotbah atau pembawa renungan) dan tidak bagi warga jemaat yang pasif. Akibatnya sangat besar kemungkinan bahwa pemberitaan itu tidak kontekstual dengan apa yang ada dalam benak, serta apa yang sedang digumuli oleh Jemaat dalam kehidupan mereka setiap hari. Paradigma ini juga bertentangan dengan makna khotbah sebagai homilia, suatu percakapan. Memang ada upaya pembelaan dengan mengatakan bahwa khotbah yang dipersiapkan dengan baik, yang didukung dengan upaya memahami keadaan jemaat, juga sudah merupakan percakapan tidak langsung. Tentu saja ini adalah "percakapan semu", tidak orisinal, dan banyak bias-nya. Mungkin juga ada yang hendak membatasi peranan khotbah sebagai memberikan visi kepada Jemaat. Suatu visi yang tidak konsisten dengan nilai-nilai dan pengalaman setiap hari dari warga jemaat akan gagal mengilhami antusiasme murni dari anggota jemaat untuk melaksanakan misi. ${ }^{31}$ Jelas juga bahwa paradigma jemaat sebagai objek bertentangan dengan hakikat ibadah sebagai perjumpaan dengan Allah, seperti yang dialami oleh Abraham, Musa dan sebagainya. Mereka berdialog dengan TUHAN Allah.

Dengan mengkritik paradigma jemaat sebagai objek bukan pula berarti saya hendak mengemukakan paradigma jemaat sebagai subjek pemberitaan firman Tuhan. Memang dalam paradigma ini jemaat aktif untuk memahami atau mengontekstualkan firman Tuhan dalam kenyataan hidup mereka setiap hari. Paradigma yang ditandai dengan pola komunikasi horizontal akan bisa menjelma seperti komunikasi antara Yesus dan iblis menurut kesaksian Matius 4:1-1l. Out put dari ibadah dengan paradigma pemberitaan seperti ini adalah para pelaksana misi yang mengutamakan kepentingan sendiri dengan mengatasnamakan missio Dei, seperti para gembala yang dikecam oleh nabi (Yeh. 34), serta orang-orang upahan yang disinggung Yesus dalam perumpamaan gembala yang baik (Yoh.10), ataupun seperti kritik Paulus terhadap mereka yang mencari keuntungan dari pemberitaan Injil (2 Kor. 2:17; 3:1). Sejalan dengan hal tersebut, Parushev berpendapat integritas misi adalah integritas kehidupan Kristen sebagai kesaksian Alkitab. Kehidupan Kristen, misi Kristen dan komunitas Kristen adalah tak terpisahkan. Misi bukanlah salah satu dari banyak pilihan untuk kinerja gerejawi. Misi adalah suatu keharusan! Itu adalah warisan dan kelahiran baru Kristen dan menjadi sarana Allah untuk penebusan dunia. ${ }^{32}$

${ }^{31}$ P. Senge, The Fifth Dicipline (New York: Dobleday Currency, 1990), 223.

32 Parush Parushev, "Witness, Worship and Presence: On the Integrity of Mission in Contemporary Europe," Mission Studies 24, no. 2 (November 1, 2007 ): 307. 
Dahill berpendapat bahwa ibadah Kristen dimaksudkan untuk berpartisipasi dalam misi Allah untuk memberikan kehidupan kepada dunia; untuk menjadi tempat di mana Roh membawa ke dalam realitas nyata kehidupan kebangkitan dan kasih dicurahkan untuk semua dalam Yesus Kristus. ${ }^{33}$ Ibadah harus menjadi fokus utama dalam gereja, dan orang percaya, dan Injil menjangkau ke dalam konteks baru, mentransformasikan orang dan budaya, "lagu-lagu baru" yang mengilhami, yang pada gilirannya, menginjili orang lain yang belum percaya. ${ }^{34}$ Dengan demikian, apapun yang terkait dengan ibadah dapat menunjang pelaksanaan misi Allah melalui gereja, dan umat-Nya.

Bila pemberitaan Firman dilihat sebagai upaya berbagi visi, maka sesungguhnya visi tersebar karena suatu penguatan proses klarifikasi, antusiasme, komunikasi dan komitmen. Ketika jemaat bercakap atau berdialog, maka visi bertumbuh semakin jelas. Kejelasan akan membangun antusiasme. Seterusnya visi mulai menyebar dalam suatu penguatan atas spiral komunikasi dan keasyikan. Jadi, membangun dan menyebar visi sebagai bagian penting daripada pemahaman dan pelaksanaan misi dapat dikembangkan melalui paradigma ini.

Paradigma ini juga menjadikan persekutuan jemaat itu sebagai persekutuan belajar (learning community). Sebagai persekutuan belajar, maka ibadah dengan paradigma ini adalah proses mempererat persekutuan sambil mengembangkan kemahiran persekutuan itu untuk menciptakan hasil-hasil yang diharapkan anggota-anggota jemaat, berdasarkan firman TUHAN. Gereja sebagai persekutuan belajar membangun disiplin untuk membangun visi bersama, kemahiran pribadi untuk kepentingan persekutuan maupun mengembangkan kemahiran individu, serta membangun kerjasama.

Hal tersebut di atas bisa dicapai karena paradigma ini mempraktikkan dialog dan diskusi. Dalam dialog ada suatu eksplorasi yang bebas dan kreatif atas isu-isu yang kompleks dan tak kentara, suatu kesediaan untuk saling mendengar secara mendalam. Dalam diskusi, pandangan-pandangan yang berbeda disajikan dan dipertahankan dan ada suatu upaya untuk mencari pandangan terbaik guna mendukung keputusan yang akan diambil.

\section{Fungsi Pemberitaan Firman Bagi Pelaksanaan Misi Allah}

Pemberitaan firman Tuhan dalam ibadah merupakan upaya untuk menjelaskan kepedulian jemaat secara bersama, sebagaimana yang

${ }^{33}$ Lisa E. Dahill, "Life in All Its Fullness: Christian Worship and the Natural

World," Liturgy 31, no. 4 (October 2016): 43-50.

34 Megan Meyers, "Contextualization Is Complicated: A Case Study of Contextualized Worship Arts in Mozambique," Missiology: An International Review 44, no. 3 (July 2016): 9-10. 
dikehendaki oleh Tuhan. Kepedulian itu merupakan suatu "draft atau rencana kasar" tentang apa yang harus dilakukan oleh jemaat guna menunaikan misi mereka. Rencana kasar itu adalah gagasan untuk mengubah atau meningkatkan kenyataan atau realitas yang dihadapi agar menjadi lebih sepadan dengan kehendak Tuhan menurut FirmanNya. Semua peserta kemudian diberi kesempatan untuk menjelaskan kepedulian mereka terhadap Firman yang diberitakan, menyimak pemikiran sesama dan kemudian berupaya untuk menemukan apa yang mungkin (feasible) untuk dikerjakan sebagai kegiatan bersama maupun pribadi. Selanjutnya kelompok merencanakan secara bersama tindakan kelompok maupun masing-masing anggota kelompok. Itulah yang dimaksud dengan proyek.

Setelah rencana tindakan disusun, segera diikuti dengan tindakan untuk mengimplementasikan rencana tersebut. Sementara itu, diadakan pengamatan atas dampak-dampak dari tindakan itu dalam konteks di mana tindakan itu berlangsung. Setelah atau sementara tindakan bersama itu dilaksanakan, diadakanlah ibadah yang berfungsi untuk berefleksi dari pengalaman melaksanakan rencana tindakan. Refleksi itu, dengan firman Tuhan sebagai titik pandang utamanya, dilaksanakan dalam bentuk diskusi di antara jemaat. Refleksi akan mengantar pada rekonstruksi makna dari situasi yang ada dan akan menjadi basis untuk perencanaan selanjutnya, lalu dilaksanakan. Refleksi mengandung aspek evaluatif. Ia mempertanyakan tindakan yang sudah dilakukan, ia menguji dampak dari proyek itu. Situasi ini akan berlangsung menjadi spiral pengujian tindakan misioner.

\section{Kesimpulan}

Kata Ibadah atau penyembahan dalam konteks misi adalah penyembahan yang terfokus kepada Allah, dan panggilan orang percaya untuk membawa orang lain untuk merespons kasih Allah bagi mereka. Ibadah dalam bentuk penyembahan, pujian, penyampaian firman Tuhan, dan melayani sesama menunjukkan implikasi misi Allah bagi gereja.

Ibadah orang percaya membawa perjumpaan dengan Allah, dan kehendak-Nya. Ibadah melahirkan visi, dan misi Allah, dan membawa orang percaya dalam disiplin rohani. Ibadah dan misi tidak dapat dipisahkan karena Allah yang menghendaki ibadah, dan akibatnya adalah misi Allah tergenapi melalui umat-Nya. Adanya ibadah telah membawa kehendak Allah dialami oleh orang percaya, dan orang percaya harus melaksanakan misi Allah bagi dunia. Umat Allah telah menjadi objek, sekaligus subjek dalam pelaksanaan misi Allah bagi gereja, dan dunia. 


\section{Kepustakaan}

Abineno, J. Ch. L. DOA Menurut Kesaksian Perjanjian Baru. Jakarta: BPK Gunung Mulia, 1992.

Abraham, K. C. Liberative Solidarity: Contemporary Perspectives on Mission. Tiruvalla: Christava Sahitya Samithi, 1996.

Barna, G. Mengejawantahkan Visi ke dalam Aksi. Jakarta: Metanoia, 1998.

Bock, Kim Yong. Messiah and Minjung: Christ's Solidarity with the Paople for New Life. Hongkong: CCA-URM, 1992.

Bosch, J. D. Transformasi Misi Kristen: Sejarah Teologi Misi yang Mengubah dan Berubah. Jakarta: BPK Gunung Mulia, 1997.

Brake, Andrew. Spiritual Formatian: Menjadi Serupa dengan Kristus. Bandung: Kalam Hidup, 2014.

Butrick G. A. et.al. (eds), The Interpreter's Bible, Vol. 8. Nashville: Abingdon Press, 1991.

Cohen David J., and Michael Parsons (eds.), In Praise of Worship: An Exploration of Text and Practice. Eugene, OR: Wipf and Stock Publishers, Pickwick Publications, 2010.

Dahill, Lisa E. "Life in All Its Fullness: Christian Worship and the Natural World." Liturgy 31, no. 4 (October 2016): 43-50.

Douglas J. D. (eds). The New Bible Dictionary. London: Inter-Varsity Press, 1982.

Kirk, J. Andrew. Apa itu Misi? Jakarta: BPK Gunung Mulia, 2012.

Meyers, Megan. "Contextualization Is Complicated: A Case Study of Contextualized Worship Arts in Mozambique." Missiology: An International Review 44, no. 3 (July 2016): 1-12.

Parushev, Parush. "Witness, Worship and Presence: On the Integrity of Mission in Contemporary Europe." Mission Studies 24, no. 2 (November 1, 2007): 305-332.

Redman, Matt. Menyembah dalam Roh dan Kebenaran. Yogyakarta: ANDI, 2010.

Senge, P. M. The Fifth Dicipline. New York: Dobleday Currency, 1990.

Tison, Jermia Djadi. "Pengajaran Tentang Ibadah Berdasarkan Surat Ibrani 10:19-25 Dan Implimentasinya Dalam Kehidupan Orang Percaya Pada Masa Kini." Jurnal Jaffray 11, no. 1 (April 2, 2013): 3766.

Tomatala, Yakob. Teologi Misi. Jakarta: YT Leadership Foundation, 2003.

Van Opstal, Sandra. The Mission of Worship. Downers Grove, Ill.: IVP Books, 2012.

Wijaya, Hengki. "Kajian Teologis Tentang Penyembahan Berdasarkan Injil Yohanes 4:24." Jurnal Jaffray 13, no. I (March 16, 2015): 77-96. 
Wijaya, H. Analisis Data Kualitatif Ilmu Pendidikan Teologi. Makassar:

Sekolah Tinggi Theologia Jaffray, 2018.

Wright, Christopher J. H. The Mission of God: Unlocking the Bible's Grand Narrative. Downers Grove, Ill: IVP Academic, 2006.

Zodhiates, S. The Hebrew-Greek Key Study Bible. Chattanooga-USA: AMG Publishers, 1986. 